\title{
7. The Transnational Uncanny Child
}

\begin{abstract}
Chapter Seven considers the Hollywood J-horror remakes and SpanishAmerican coproductions that emerged in the early 21st century as a response to the globally successful boom of uncanny child films. The chapter considers how this assemblage of films is self-consciously transnational, as the uncanny child becomes disconcertingly ungrounded from specific visions of national identity. In these films, the uncanny children stage direct confrontations with the child's shifting role in postmodern culture. Through their cultural hybridity, the uncanny children in transnational horror navigate tensions underlying not only shifting understandings of childhood but changing global cinema cultures in the early 2000 s.
\end{abstract}

Keywords: Transnational cinema, Childhood, Globalization, Deterritorialization, Cultural hybridity

Through their deployment of uncanny children who expose and trouble the child's overdetermined, sometimes paradoxical temporal function, all the films discussed in this book so far communicate with one another in profound ways. Previous chapters have outlined how the uncanny child emerges from culturally specific contexts as an embodiment and agent of trauma at the turn of the 21st century, aestheticizing a breach in linear narratives of personal and national identity. The uncanny child is thus a product of this unsettled moment of transition in which entrenched historical narratives seemed to waver, harnessing this liminality to problematize the child's imbrication in progressive temporal modes with specific cultural functions. Though these films emerge from and speak to culturally specific contexts, they exchange themes and aesthetics in a manner that helps them to envision new ways for the child to erupt through its symbolic bounds at the millennial turn, as traditional understandings of childhood's symbolic function started to come undone.

Balanzategui, J., The Uncanny Child in Transnational Cinema: Ghosts of Futurity at the Turn of the Twenty-First Century, Amsterdam University Press, 2018.

DOI: $10.5117 / 9789462986510 / \mathrm{CHO} 7$ 
For instance, the character design for child-ghost Santi of THE DEviL's BAсквоNE was inspired by the ghostly children of J-horror: ${ }^{1}$ his white, cracked skin and black, reflective eyes echo the traumatic aesthetics typical of the Japanese child-ghost, but reinscribed to refract Spanish cultural traumas about the Civil War's effects on childhood development. Del Toro's drawing from J-horror also points to the ways the film was positioned as both a culturally specific and transnationally digestible product. As Lázaro-Reboll points out, 'the film targeted not only the expanding Spanish and Latin American markets but also a wider international audience. The film was distributed through a truly global film cartel and pre-sold heavily to many major territories' (2007, 39). Lázaro-Reboll also suggests that 'the allegorical intentions of the film are neatly translated into American generic forms' $(2007,43)$ - and indeed, the eerie pairing of the child-ghost with the child seer who communicates with him echoes American films The Sixth SENSE and Stir of EchOES, analysed in Section One, both of which came out two years prior to BACKBONE. THE ORPHANAGE, another Spanish film discussed in Section Two, and a film that del Toro produced, was similarly successfully positioned for global audiences through a carefully tailored blend of cultural specificity and transnational legibility. As Lázaro-Reboll (2012) explains, not only did the film maximize 'the bankability and reputation of del Toro', with the tagline 'Produced by Guillermo del Toro' acting 'as a guarantee of access to international markets' (226), but the film 'displayed the production values usually associated with Hollywood film' (227) while recalling the themes and aesthetics of classic Anglophonic ghost films, in particular seminal creepy child film THE INNOCENTs (Jack Clayton, 1961). The uncanny child figure is at the core of both films' positioning for global markets, as is most strongly indicated by the influence of J-horror's child-ghosts upon del Toro - J-horror being another supposedly 'national' cinema thrust into the global mainstream during the millennial turn.

Similarly, while the uncanny children of J-horror modulate kaidan folklore and Japanese literary tropes, the generic focus on the child is also strongly influenced by American horror films of the 1970s and 1980s. In fact, Suzuki, author of the book series upon which the RING franchise is based, has suggested that Carol Anne from POLTERGEIST was a direct inspiration for Sadako, while director Nakata claims that classic monstrous child films THE EXORCIST and THE OMEN influenced his work (Anthony Enns, 2010, 31). Lowenstein reads the mediated circuits of transnational influence as a key preoccupation of RINGU's diegesis, suggesting that the film plays out an anxiety that 'the

1 In various interviews and discussions about the film del Toro has suggested the ways that 'J-horror intersects with The DeviL's BAcквone' (del Toro, 2012). 
technologies that promise to erase boundaries between people scattered across the globe fulfil their promise - only too much so. It is not just the boundaries that are erased but the people themselves as well' $(2015,83)$. He proposes that RINGU and its American remake in fact suggest "a "superflat" global portrait: a simultaneously "Japanized” America and "Americanized" Japan that belongs to both nations but is not fully locatable in either' $(2015,84)$.

Furthermore, the Ju-ON cycle is distinctively marked by cultural hybridity, with the ghosts acting very much like the stalker/slasher killers of American horror: McRoy describes Ju-ON as a 'curious filmic hybrid, combining carefully chosen aesthetic trappings of western - particularly US - horror films with visual and narrative tropes long familiar to fans of Japanese horror cinema' $(2005,176)$. In addition, REINCARNATION (2005), another uncanny child Jhorror film directed byJu-ON's Shimizu, clearly echoes THE SHINING in its tale of a haunted hotel and a father driven to murder his family within its walls: throughout the film, 'Room 227' is prominently featured, a reference to THE SHINING's infamous Room 237, and the central ghost-girl's repeated declaration 'We'll be together forever' throughout the film recalls the Grady twins' 'Play with us forever and ever.' Thus, as in the Spanish films, the uncanny child trope in J-horror represents the locus for processes of transnational exchange: this is at the thematic and aesthetic core of these films while also being a key element transposed from an American into a Japanese cultural context. In turn, subsequent to the global popularity of the RING and JU-ON franchises, the child-focused J-horror cycle came to change the shape of the horror genre globally through both direct remakes from countries as diverse as America, Korea, and Turkey ${ }^{2}$, and films which drew from the themes and aesthetics of J-horror yet constructed original, often culturally specific, narratives, such as Australia's LAKe Mungo (Joel Anderson, 2008) and the Spanish-BritishBulgarian coproduction THE ABANDONED (Nacho Cerdà, 2007).

In fact, aside from the new subgenre known as torture porn, a fair proportion of Hollywood's horror output in the first decade of the 2000 s consisted of remakes of Japanese supernatural horror films. Such films include THE RING (Gore Verbsinki, 2002) and its sequel The RING Two (Hideo Nakata, 2005), The Grudge (Takashi Shimizu, 2004) and its two sequels The Grudge 2 (Shimizu, 2006) and 3 (Toby Wilkins, 2009), DARK WATER (Walter Salles, 2005), and One Missed CALL (Eric Valette, 2008). Contributing to this resurgence

2 Apart from the well-known cycle of American remakes canvassed in this chapter, there has, for instance, also been a Korean remake of RINGU - THE RING VIRUS (Dong-bin Kim, 1999) - and an unofficial Turkish remake of critically acclaimed J-horror film PULSE (Kiyoshi Kurosawa, 2001) called D@BBE (Hasan Karacadag, 2006) (which also draws heavily from RINGU). 
of supernatural horror films were Spanish-American coproductions THE OTHERs (Alejandro Amenábar, 2001) - which was, alongside THE RING, one of the most critically and commercially successful horror films of the early 21st century ${ }^{3}$ - DARKNESS (Jaume Balagueró, 2002), and Spanish-British coproduction FragiLE (Balageuró, 2005), starring American actress Calista Flockhart and distributed and promoted in the U.S. by Metro-Goldwyn Mayer. While these films share a subgeneric status as supernatural horror films, the thematic and aesthetic link which binds them is the uncanny child. Thus, the cycle of transnational horror films that emerged in the early years of the new millennium illustrates the extent to which American, Japanese, and Spanish supernatural horror films engage with one another through the traumatic temporal contortions wrought by their uncanny child figures. Chapter Seven presents a discussion of these remakes and transnational coproductions, outlining how these films can be considered transnational amongst broader discussions of the 'decline' of American horror in the early 21st century, while suggesting how these films self-consciously confront the implications of transnationality through their uncanny children.

\section{Transnational Horror Film}

The assemblage of uncanny child films that emerged alongside and subsequent to the more culturally specific American, Spanish, and Japanese cycles ${ }^{4}$ analysed in previous chapters are transnational in a number of different senses, despite being marketed as Hollywood products. ТнЕ ОтнERS, DARKNESS, and FrAGILE were developed by creative teams from Spain, while coproduced by American, Spanish, and, in the case of FragILE, British companies. ${ }^{5}$ The Grudge franchise and The RING 2 were codeveloped by

3 THE RING is currently among the 20 highest-grossing horror films of all time and is the most commercially successful horror remake. It received $72 \%$ on rottentomatoes.com, a website which aggregates the reviews of film critics, a relatively high score for a horror film (and particularly high for a Hollywood remake). THE OTHERs holds a review aggregate score of $83 \%$, and was the fourth highest-grossing horror film of the 2000 s.

4 Many of the films discussed in this chapter came after the influential American, Japanese, and Spanish films discussed in previous chapters: obviously, the J-horror remakes are based on, and subsequent to, the Japanese originals. However, the transnational cycle flourished alongside some of the more culturally specific films previously discussed, a condition which furthered the transnational potential and global popularity of these films: for instance, THE Devil's BACKвONE was released in the same year as The Others (2001), and The OrPHANAGE (2007) came at the tail end of this transnational horror boom.

5 The Others was coproduced by Cruise-Wagner Productions and Spanish companies Sogecine and Las Producciones del Escorpión, DARKNess by Castelao Producciones and U.S. 
creative teams based in both Japan and America. The first two GRUDGE films and THE RING 2 were directed by Takashi Shimizu and Hideo Nakata respectively - the directors of the Japanese originals - and THE GRUDGE franchise was largely filmed in Japan. The other J-horror remakes - THE RING, DARK WATER, and ONE Missed CALL - were developed by American creative teams; however, their screenplays are based on the Japanese originals and, in all cases except THE RING, the writers of the Japanese originals are acknowledged in the credits as having cowritten the screenplays. In addition, ONE MisSED CALL was coproduced by Hollywood company Alcon Entertainment and the Japanese company that produced Takashi Miike's original film, Kadokawa Shoten. While not all of the J-horror remakes were coproduced by both Hollywood and Japanese companies, all of them function as self-conscious reinterpretations of the aesthetics and ideological preoccupations of the original Japanese films. Thus, they are transnational in the sense that they mediate the channel between cultures, and resist simple definition as American or Japanese products. All of these films are thus the types of films to which Christina Klein refers in her assertion that:

in recent years the once unambiguously 'American' horror film has been challenged by films that have been profoundly shaped by Hollywood, both directly and indirectly, but that cannot be classified as American in any simple way [...] the horror film is becoming - and is being recognized - as a transnational genre. $(2010,3)$.

In all cases, the films under discussion were codeveloped by production companies or creative teams across cultures, or, at the very least, function as interpretative bridges between national contexts, and are designed to be accessible to diffuse, global audiences.

Elizabeth Ezra and Terry Rowden describe such 'Hollywoodization' processes in wholly negative terms, referring to the 'homogenizing dynamic' of Hollywood film production:

the U.S. film industry has perhaps irreversibly committed itself to the production of empty and costly cinematic spectacles that, in order to maintain their mainstream inoffensiveness, must be subjected to increasingly thorough forms of cultural and ideological cleansing before being released into the global cinemascape. $(2006,2)$ 
In particular, the Hollywood remakes of J-horror films that dominated the horror genre in the early years of the new millennium faced widespread denigration in popular and academic commentary, and were considered to be an indication that the American horror genre was in crisis in the early 200os. As Steffen Hantke points out, most academic criticism focused on the American horror genre published in the first decade of the 21st century 'agree[s] with the notion, explicitly or implicitly, that the [horror genre] [...] is currently in a state of crisis' (Hantke, 2007, 199), as is evidenced in particular by Hollywood's 'indiscriminate plunder of Asian horror films - a practice that, as it confirmed the vitality, creativity, relevance, and intensity of horror film in other countries, made the lack of these qualities strikingly obvious in American cinema' (Hantke, 2010, ix). Disdain for American remakes of Asian horror films is also related to valid concerns surrounding the colonization and appropriation of national genres for Hollywood profits, as is suggested in the work of Balmain (2008), Lim (2009), and McRoy (2008).

Often implicit in the widespread vilification of Hollywood's practice of remaking J-horror films, however, is an anxiety about J-horror's disturbance to a distinctly American horror genre, as the explicit and visible process of global exchange that came to constitute the horror genre in the early 20oos destabilized binary separations of 'American' and 'Japanese' national cinemas. As Klein points out, 'remakes severely problematize familiar notions of cinematic style and cultural identity' $(2010,7)$, as they are defined by their intertextual relationship with the original upon which they are based, and hybridize tropes and styles that were previously considered culturally specific. Some of the popular and scholarly anxieties about Hollywood's rampant remaking of Asian horror films in the early 21st century could thus arguably relate to the ways that transnational horror films suggest the destabilization of a clearly definable American product. ${ }^{6}$

The interplay between Hollywood 'homogeneity' and cultural specificity permeates all of these films: for instance, DARKNESS and THE GRUDGE are set in Spain and Japan respectively, and feature well-known Spanish and Japanese actors who were relatively unknown in a Hollywood context, such as Fele Martínez and Takako Fuji, alongside Hollywood stars such as Anna Paquin and Sarah Michelle Gellar. In addition, these films exhibit the distinctive styles of Balagueró and Shimizu, new within a Hollywood

6 For instance, film critic Joe Queenan decries J-horror remakes before stating 'western directors are trying to shoehorn Asian films into a culture that cannot fully accommodate them' (2008), while Joshua Rothkopf, states 'it's hard to know what's scarier - the fact that Asia keeps producing these movies or that Hollywood keeps remaking them' (2008). 
context at this time but recognizable to fans of Spanish and Japanese horror cinema. Furthermore, THE OTHERS was marketed internationally as a Hollywood production, as enhanced by the presence of Nicole Kidman as lead actress and her then-husband, Tom Cruise, as executive producer. ${ }^{7}$ Yet, THE ОтнеRS was considered to be a Spanish product in Spain (titled Los отROs), and won the best picture award at Spain's national film awards ceremony, The Goyas: the first English-language film to be bestowed with the award. The film was also, at the time, the highest-grossing Spanish film ever released. Ultimately, while a surface consideration of these films suggests Ezra and Rowden's 'homogenizing dynamic', their navigation of the circuits between cultures and spaces of belonging - as embodied by the culturally hybridized uncanny child - upsets straightforward assumptions of Hollywood cultural homogeneity.

The culturally ungrounded nature of these remakes and coproductions underwrites their themes and aesthetics, and, in particular, their construction of the uncanny child. This model of uncanny child, untethered from specific national contexts, comes to be a cipher through which ontologies of childhood and progress can be rewritten in the new millennium, heralding a globalized, postmodern era in which linear teleological frameworks and clearly defined national identities fall away. Ezra and Rowden suggest:

like postmodernism and poststructuralism, other discourses that have complicated the notion of unmediated representation, transnationalism factors heterogeneity into its basic semantic framework [...] Transnational cinema arises in the interstices between the local and the global [...] [and is] most "at home" in the in-between spaces of culture. $(2006,4)$

This characterization of cinema conceived and produced between national boundaries parallels the deterritorialized workings of the transnational uncanny child: deterritorialization being a Deleuzian term that expresses a 'coming undone' (Deleuze and Guattari, 2004, 354), a decontextualization from established ideological relations and structures ${ }^{8}$, which, in the very process of this coming undone - this 'movement of deterritorializaton' -, 'pushes the simulacra to a point where they cease being artificial images

7 The film attracted pronounced media attention for the collaboration between Kidman and Cruise because the film was released in the midst of their high-profile divorce.

8 Deleuze and Guattari first use the term to discuss the freeing of labour power from the original or specific means of production, and in their discussion of 'schizoanalysis' to mark a breaking loose of psychic energy from the heavy ideological anchor of the Oedipal complex (both conceptually and psychically). 
to become indices of the new world' (2004, 353-354). Deterritorialization, in the words of Adrian Parr, works to 'free up the fixed relations that contain a body all the while exposing it to new organisations' (2013, 69).

The term has 'deterritoralized' from Deleuze and Guattari's original context (as Deleuze endorses throughout his oeuvre), to become commonly used in discourse about globalization to chart how processes of cultural exchange release meanings and identities from clear and specific cultural grounding, yet inscribe them with new meaning in the course of this ungrounding. As globalization scholar John Tomlinson states 'deterritorialization is [...] the major cultural impact of global connectivity', and he uses the term to explore how this 'complex connectivity weakens the ties of culture to place' and enacts 'the dislodging of everyday meanings from their "anchors" in the local environment' (1999, 29). Transnational uncanny child films self-consciously express anxieties about this process of cultural deterritorialization. As McRoy emphasizes, transnational horror is an 'ideal forum for the metaphoric expression of concerns over an indiscrete (or hybrid) national, social or corporeal body' $(2008,93)$. In these transnational horror films, the uncanny child is deterritorialized from clear origins and is inscribed with a cultural hybridity: a condition of the processes of remaking and transnationally codeveloping films for vaguely defined global audiences. In turn, through their self-conscious transnationality, these films tend to engage in meta-textual encounters with the shifting ways in which cinema is produced and consumed in globalized, postmodern media culture.

As a result, in contrast with the films analysed in previous chapters, the transnational horror films of the new millennium displace a concern with the uncanny child's disruption to coherent narratives of national identity to contemplate the breakdown of the very notion of contained national identities. While Ezra and Rowden would read the more generalized construction of uncanny childhood which results from this preoccupation as a symptom of Hollywood's 'homogenizing dynamic', I see this process as a culmination of the uncanny child's conceptual relevance between the cultures of America, Spain, and Japan at the turn of the millennium, as the uncanny child is imbued with global resonance in the early 21st century as a figure who resists containment within the established ideological bounds of adult-centric discourse and culture. The supernatural disturbances of the uncanny children in all of these films emerge from displacement and alienation. The films pivot on an anxious expression of deterritorialization, as a sense of home and belonging gives way to the unhomely disquiet of the 'non-place', isolated or detached from the society beyond its bounds. The transnational uncanny child thus thematizes the disintegration of 
cultural belonging in ways both symbolic and direct. As Ezra and Rowden suggest, transnational cinema tends to foreground 'a sense of being out of place' as 'identities are necessarily deconstructed and reconstructed' and 'identification with a "homeland" is experienced and represented as a crisis' (2006, 7-8). It is this very sense of crisis that facilitates the uncanny child's deconstruction of enclosed cultural identities - based as they are on a tight historical continuum of past, present, and future - and opens a space for childhood's conceptual reformulation.

\section{'At The Back of Beyond':}

\section{Place in Spanish Coproductions and Japanese Remakes}

In the Spanish films discussed in Section Two, the uncanny child embodies the aesthetics and temporal disjunction of trauma to trouble historical narratives that distance the post-Civil War past from Spain's 'hyper-modern' present. However, in transnational films THE OTHERs, DARKNEss, and FRAGILE - performed in English and aimed at global audiences - specific Spanish historical narratives are no longer a viable source from which to draw. Instead, these films self-consciously reflect the culturally liminal conditions of their production. As is indicated by the film's opening title, THE OTHERs is set in an isolated mansion on the island of Jersey, a bailiwick off the coast of France that is a possession of The Crown in the Right of Jersey (thus, it is a self-governed entity with symbolic ties to the British Crown). Enhancing the geopolitical ambiguity of this setting, the mansion is cut off by dense woodlands and thick fog from the rest of the community and when the protagonist, Grace, ventures into the woods in order to seek help for herself and her children, her passage is blocked by disorienting fog.

In a setting which is similarly culturally interstitial, FRAGILE is set in a children's hospital on the Isle of Man that is soon to be shut down: a remote, inaccessible place that is in the throes of decay, dilapidation, and abandonment. The Isle of Man is itself a culturally ambiguous location in the Irish Sea between Great Britain and Ireland, with an independent parliament and government that directs most domestic matters but whose defence is the responsibility of the United Kingdom. In FragILE, the island hospital is inhabited by staff and patients from an array of different nationalities: while the actors perform in English, they speak in a range of different accents (Spanish, British, American, and Portuguese). The spatial and cultural liminality of the hospital underscores the film's horrors: as is exacerbated by the island location, the hospital is short-staffed and cut off from supplies. As one character proclaims early in the film, 'it is at the back of beyond', and, 
even when a helicopter arrives to transport the children to the mainland, a storm prevents its transit. The ghost in the film - strongly influenced by J-horror - is like a spectral force of cultural dislocation: she draws her power from the decaying hospital and the sick and dying children within it, and desperately tries to keep them in this isolated, dilapidated space. ${ }^{9}$

DARKNESS centres on an American family who have recently moved to an old, dilapidated house in Spain that has never been lived in. The house is on the rural outskirts of a city which is never specifically defined (the only geographical context is provided by the opening subtitle superimposed over an establishing shot of the house, which reads 'Spain'). The multicultural nature of the cast is evidenced through their varied accents, as their contrasting, contrived performances of American English further amplify the eerily ungrounded nature of the setting: the father is portrayed by Scottish actor Iain Glen, the mother by Swedish actress Lena Olin, and the two children are played by Canadian-New Zealand actress Anna Paquin and Swedish-Spanish actor Stephan Enquist. Diegetically reflecting the cultural ungroundedness of the film's production, the young protagonists experience a pervasive disquiet in their new environment which conflates their sense of cultural displacement with their fear of the child-ghosts in the eerie house.

Similarly, in translating the Japanese originals into Hollywood products, the J-horror remakes construct ambiguous settings that loosen the characters' roots in place, and similarly set the audience adrift in eerily undefined, hybridized, or isolated landscapes. In translating the Japanese originals into a globalized, Hollywood context, the echoes of the original Japanese locations reverberate in generalized terms. These films do not simply reconfigure the settings of the Japanese originals to resonate with American preoccupations in a straightforward process of cultural translation. Instead, these spaces refract an unsettling cultural emptiness that intensifies the lack of belonging and sense of unhomeliness that the characters experience.

As outlined in the previous chapter, in RINGU, the islands of the Izu peninsula on which uncanny child Sadako lived and died resonate with

9 In a manipulation of the generic expectations of the uncanny child cycle, all the characters (and the audience) are led to assume that this terrible ghost was a child who died in the hospital throughout the film. The twist, however, reveals that, in fact, the ghost was one of the nurses: so dependent was the woman's identity on her vulnerable patients that she kept her young charges ill to ensure that they remained confined in the isolated hospital. Eventually, this sadistic behaviour led to the death of her favourite patient, causing the nurse to lose her sense of purpose and to take her own life. Fragile thus self-consciously plays with and draws out the themes of the uncanny child cycle, placing the adult nurse's monstrously pathological dependence on the mythology of the weak, innocent, and vulnerable child at the core of the film's horrors. 
millennial Japanese anxieties about the troubling of long-valued paradigms of economic advancement and urbanization in what has become known as 'the Lost Decade'. By contrast, the remake THE RING is ostensibly set in Seattle - as we learn through protagonist Rachel's job at the Seattle PostIntelligencer - although the specifics of the city are barely referenced by either name or visual markers, as the city scenes largely take place within either Rachel's or her ex-partner Noah's apartments. By contrast to the original, in the remake, the island on which Samara (the film's version of Sadako) once lived is a fictional site called Moesko Island. The film retains the original's implications that the island has been left behind by mainland society: Moesko is a fishing village and farming community in a state of physical and economic deterioration. However, because the island is fictional, the specific contours of a historical narrative and cultural consciousness are stripped away, and the island becomes a generalized evocation of present-becoming-past. Furthermore, unlike Izu in RINGU, the rural area at which Samara was murdered - Shelter Mountain - is another fictional site that has unclear geographical relations to the film's other settings. Shelter Mountain's distance from Seattle is only indicated by the numerous montages of high-angle shots that depict Rachel travelling along densely forested roads to get there. Thus, like Moesko Island, the site where Samara's body decomposes in the well is a vaguely defined archetype of rural isolation, as is emphasized by the ironic name 'Shelter' Mountain, which serves to draw attention to the distinct unhomeliness of the space. As in the original, Shelter Mountain is now a tourist destination, but was an expansive, rural property when Samara was murdered.

The entwined vagueness and uncanniness of both locations is visually reinforced by a thick veil of fog, and cinematography suffused with a bluegrey filter, which evokes the sense that the spaces are underwater. Samara herself embodies this uneasy sense of deterritorialization. In contrast to Sadako, an illegitimate child whose taboo origins implicitly play a role in her murder, Samara is adopted from somewhere unknown across the ocean. Her supernatural curse, which defies rational explanation and containment, wreaks havoc on the previously secure identities of her adoptive parents, leading Samara's adopted mother to murder the child. Yet, even after Samara's death, her uncontainable curse torments her adoptive parents, eventually driving both to suicide. It is as if the child's curse emerges from the unknowability of her origins.

THE GRUDGE is set in Tokyo, like the Japanese original - the same location is even used for the haunted house - but the plot focuses primarily on a group of American expatriates unsettled in their new environment. The 
enigmatic powers of the uncanny child, Toshio - who is played by the same actor, Yuya Ozeki, as in the original - seem to ripple out from this cultural discord. The eeriness of the child is associated with the American characters' inability to communicate with him: when protagonist, Karen, first sees the child, she asks his name, to which he abrasively and gutturally replies 'Toshio', drawing out each syllable in a disconcerting way. This is the only discernible word that the child utters throughout the film. From this point on, Toshio is only ever heard issuing catlike wailing sounds, which, by contrast to the original, seem in the remake to underscore the ghost's incomprehensible speech to the non-Japanese speaking leads. The child's 'Japanese-ness' is thus emphasized as an uncanny occlusion of the channel of communication between him and the English-speaking progagonist. ${ }^{10}$ Thus, THE GRUdGe positions the turbulent flows between Japanese and American culture central to the narrative. As a result, Wee suggests that THE GRUdGe troubles the very definition of 'remake':

Labelling THE GRUDGE an American remake [...] has the effect of potentially oversimplifying the identity politics associated with and expressed within the film [...] this straightforward distinction between American Self/Oriental Other is complicated by THE GRUDGE's sometimes ambiguous status as simultaneously both inherently "Japanese" - it is directed by the same Japanese director who was responsible for the original film; it is set in Japan; and features many of the same Japanese characters as in the original - and an American remake, as signalled by the film's revised script; Hollywood financing, production, and distribution practices; and the inclusion of American/"foreign" characters. This somewhat "blurred" nature of the film's national/cultural origins and identity raises some interesting questions regarding THE GRUDGE's cultural politics. (emphasis in original, 2013, 139)

Indeed, as opposed to revolving around a clearly established and orientalist self/other binary (as some critics, such as McRoy [2005] and Lim [2009], have suggested), THE GRUDGE is characterized by a distinct instability of

10 This point is directly parodied in SCARY Movie 4 (David Zucker, 2006), in which Cindy (a caricature of THE GRUDGE's Karen) tries to communicate with Toshio using mock Japanese (a string of Japanese terms appropriated by American culture). The subtitles indicate that the boy has replied 'Your Japanese dishonours my ears', when, in fact, he too is simply listing Japanese words well-known in Western culture (such as sushi), and the names of transnational Japanese-based companies. The film thus plays with the troubled processes of cultural translation inherent to the 'horrors' of The GRUDGe. 
subject positions, largely as a result of the film's fractured, episodic structure (carried over from the Japanese originals). Throughout, the film fluidly shifts focus and identification between different characters, both American and Japanese. This structure also results in a continually shifting sense of what constitutes foreign/other and domestic/self. This fluctuating cultural identification is even reflected in the critical discourse surrounding the film: while Wee positions the American characters as foreign, Lim positions the Japanese space in which the film is set as foreign: 'The title word, grudge, describes not only the trauma-stained house but also the resentment the American expatriate harbors toward a foreign social space that, for its part, destroys rather than accommodates her' $(2009,217)$.

In fact, the film as a whole, its setting, and its various characters are not clearly situated on either side of the self/other, domestic/foreign divide. THE GRUDGE anxiously destabilizes this binary altogether, instead emphasizing the uneasy channels between enclosed national identities and modes of cultural belonging. Both Japanese and American characters fall prey to the ghosts, and none of the characters are able to resolve or suppress their supernatural curse. The subsequent films in the American GRUDGE franchise depict the curse extending its reach beyond Japan and into an apartment block in Chicago, a monstrously spectral representation of globalization and the dissolution of cultural boundaries.

\section{Deterritorialized Technologies and Temporalities}

In tandem with their ungrounded settings, these transnational uncanny child films - drawing on the prosthetic technologies of J-horror - tend to be fixated with anachronistic, malevolent, or faulty technologies that disturb narrative continuity and advancement. The diegetic emphasis on technological malfunction or flux is associated with the films' meta-textual consideration of the dynamics of transnational film production. As Brenda Walter suggests:

Through remakes and transformations, regional tales of vengeful ghosts and cursed pasts are culturally adapted, internationally disseminated, and instantaneously transmitted into our homes through digital devices and networks such as the Internet. The resulting transnational and transmedial matrix of fear blurs the boundaries between original and remake, foreign and native, sender and receiver, and creates a web of postmodern horror mediated by digital technology, one in which distant ghosts and curses might become our own. $(2014,17)$ 
Walter's characterization of 2000 s transnational horror points to how the technological anxieties of these films confront the global circuits that have increasingly underpinned film culture since the early 21 st century. The disembedding of cultural anxieties from their original contexts in these films parallels the extra-diegetic process of deterritorialization facilitated by globalized, digital, and on-demand access to cinema that was gaining popularity during this period. The tensions underlying this process are reflected in various ways by the films' diegetic technological preoccupations: in many of these coproductions and remakes, antiquated, inadequate technologies with staid groundings in the material ensure that the characters become disassociated from any sense of community, emphasizing the extent to which belonging in the global community of the 21st century is technologically determined and defies material roots. Yet, somewhat paradoxically, these films also tend to anxiously express the implications of all-encompassing technological shift, as images, stories, and people are deterritorialized from geopolitical and sociohistorical contexts. No longer circulating around specific national pasts, these films construct generalized evocations of technological antiquity and obsolescence that stand in for a sense of 'pastness' and historical consciousness.

For instance, THE OTHERS is ostensibly set in 1945, the year that WWII ended, yet the house has no electricity, and thus there are no radios or telephones to connect with the world beyond the mansion's grounds, so the characters remain unsure of the status of the war. Grace explains that her family learned to live without electricity because the 'Germans kept cutting it off', but we are given the sense that this lack of electricity actually relates to the children: both children suffer from potentially lethal photosensitivity - they cannot venture into the light, or they will break out in sores and blisters. As a result, the curtains are always closed and Grace traverses the house using gas lamps, which gives the film the aura of a Victorian - rather than a post-WWII - setting. The film's technological anachronism is crystallized in a scene in which Grace discovers a large box of Victorian-era postmortem photographs in one of the house's bedrooms. This technological collapsing together of time periods is entwined with the film's plot, as, unbeknownst to them, Grace and her children are already ghosts from a bygone era. Like the new housekeepers, who are in fact ghosts from the Victorian period and appear as corpses in one of the eerie 'Book of the Dead' photographs, progress has displaced Grace and her family in favour of the house's new occupants.

Similarly, THE RING, like the original film, centres on a cursed VHS videotape. However, in 2002, the year of the film's release, many audiences 
would have watched this film about a videotape curse on DVD or via digital film projection: DVD had replaced VHS as the dominant mode of home entertainment by 2001, and, by the time of THE RING's home entertainment release in 2003, the obsolescence of VHS was imminent (Benson-Allott, 2013, 1). Furthermore, while VHS remains the mode that is copied, exchanged, and shared in The RING, 'by the time The Ring came out, videotapes were no longer the most common platform for illicit viewing; that distinction had passed to DVD and the Internet' (Benson-Allott, 2013, 103). In fact, Benson-Allott rightly suggests that the complete lack of DVDs in Verbinski's film is 'an absence so unlikely it constitutes a structuring lack' $(2013,103)$. As will be seen in Chapter Nine, the strange lack of DVDs in the film is related to its fixation with the decay of analogue materiality and concomitant uprising of uncontainable, ephemeral digital images.

The conflicted technological anxieties of these films can be aligned with the rapid process of digitization that was, at the time, changing how films were disseminated and consumed, heralding a new level of cultural exchange and hybridity that made the destabilization of 'national cinema' paradigms clearly visible. In addition to DVD, accessing films online became increasingly popular following the rise of informal streaming and peer-to-peer file sharing in the early 2000s: as Ramon Lobato (2012) outlines, these illegal or grey digital circulations - which he calls 'shadow film economies'- had started to reshape film culture prior to the emergence of official streaming services such as YouTube (2005) and subscription video on demand services like Netflix (which started offering a streaming service in 2007). As Lobato suggests, during this period, we see 'industrial processes of distribution give way to amorphous practices of decentralised content sharing' (2012, 6), which also amounts to the decentring of the official practices of global cinema circulation such as national film festivals and clearly marked sections in home entertainment stores. These official distribution practices place relatively clear borders around national cinemas in ways not present with on-demand digital access to films nor online purchase of DVDs. In tandem, digital film projection, distribution, and recording became increasingly popular following the pioneering 1999 digital release of THE РнANTOM MenaCE (Lucas). By 2011, celluloid was facing obsolescence as digital cinema and projection started to become the dominant mode of exhibition. ${ }^{11}$ Chuck Tyron contends that these technological shifts transformed the "very idea

11 See David Hancock (2011) and Nick Allen (2011). However, John Belton (2012) has demonstrated the transition from celluloid to digital projection was not necessarily a smooth or particularly rapid one, and accelerated significantly following the uptake of digital $3 \mathrm{D}$ in the mid 2000 . 
of the film text [...] turning a tangible artefact - a filmstrip - into digital code. As David Bordwell bluntly reminds us, "films have become files"' (emphasis in original, 2013, 2).

These developments helped to facilitate the rise of transnational horror cinema in the early 2000 s and drive its global popularity: for instance, Wada-Marciano points out that the global success of millennial J-Horror was strongly influenced by the efficient new digital production and distribution technologies being embraced by Japanese horror filmmakers and distributors at the time, which in turn helped J-Horror to challenge 'the long-standing flow of capital and culture, i.e. the centrality of Hollywood' (2009, 15). The global success of J-Horror of course in turn led to the production of transnational remakes such as THE GRUDGE. In addition, this context of technological change influenced the films' thematic fixations with loosening cultural ties and detachments from precise historical contexts. In their writing on transnational horror, Dana Och and Kirsten Strayer point out that 'contemporary horror media highlights the limitations of keeping [cultural] considerations discretely separated. [...] Indeed, what we see in contemporary horror is a constant flow of affinities and ideas, in which histories and styles become flattened, mutated' (2014, 1-2). Walter further suggests such a combined cultural and technological deterritorialization, a 'frameless and formless abjection' incarnated by digital media, in which:

terrifying images and horrifying tales circulate from one region and home to another along a digital web and are culturally reshaped in an ever-spinning fractal of tropes and transformations, both changing and being changed by the cultures they encounter, in a seemingly perpetual circuit of ghastly transmissions. $(2014,28)$

Transnational uncanny child films mediate these entwined technological and conceptual contortions, as film is displaced from its material, geo-spatial contexts in simultaneity with the loosening of the ligatures of national cinemas and identities.

\section{The Culturally Hybrid Uncanny Child}

That the uncanny children are the locus for these anxieties about combined technological and cultural deterritorialization is evidenced through their cultural hybridity and obscure origins. Samara wears a white gown like her predecessor, Sadako, and her face is usually shrouded in lank dark 
hair, although the specific cultural implications of the onryō, Kabuki, Noh, and Butoh are only distant reverberations within this child character. Unlike Sadako, Samara does not directly engage with anxieties surrounding the child's growth during Japan's Lost Decade. As a result, her age is unambiguous: in contrast to her Japanese predecessor, Samara is clearly defined as a child throughout. Samara retains Sadako's relentless pursuit of vengeance, the key semantic function of the Japanese onryo (vengeful ghost), which is aligned with Sadako's ideo-aesthetic rebellion against Japanese ideologies of progress. However, Samara's quest for revenge is depicted as monstrously motiveless and inscrutable now that the character is unhinged from Japanese culture. While her white dress is clearly modelled after her progenitor's onryō-esque gown, Samara's outfit, now a white prairie dress worn with leather T-Bar sandals and white socks, is visually reinscribed to situate her alongside the terrible children of American film culture, such as Rhoda of THE BAD SEED and Regan from THE EXORCIST, who wear similar outfits symbolic of traditional Western childhood purity and innocence (a visual construction that serves to highlight their perversion of these qualities).

While visually appearing as a hybrid of American and Japanese uncanny children, a brief glimpse of Samara's birth certificate maintains her vague links to Japan: the document is written in kanji, yet this kanji is virtually indiscernible and is not translated or explained. Balmain suggests that the birth certificate is an indication of the film's problematic exoticization of Samara's 'Japanese-ness' - a sign of her 'oriental alterity and implacable foreignness' $(2004,72)$. I contend that this vague and quickly passed over suggestion of Japanese origins functions as a meta-textual reference to the original film that adds another layer to Samara's hybrid unknowability, further muddying the audience's and protagonist's grasp on her origins rather than clarifying her existence or situating her within a clear cultural context. It is not Samara's Japanese otherness that monstrously contaminates the world into which she is brought, but her resistance to a single, legible history and cultural tradition. Underlying her monstrosity is the fact that she has no stakes in the future of Japanese nor American culture, for she is untethered from both.

Similarly, the two children of THE ОтнеRS are self-consciously situated alongside a long history of supernatural British cinema, appearing and behaving like stereotypical visions of Victorian British childhood: in particular, they are clearly modelled on Miles and Flora from THE INNOCENTS (1961), Clayton's film version of Henry James's The Turn of the Screw. Yet this self-aware grounding in British narrative traditions is interrupted 
by the fact that the film is an American-Spanish coproduction, and is not set in Britain, but on the island of Jersey (on which English is the dominant language, but French and the indigenous language of Jèrrais are also spoken). This isolated location is continually emphasized throughout the film. Furthermore, while THE OTHERs self-consciously upholds a vaguely British-Victorian style - largely through its child characters - the colour palette, rather than evoking the dark, shadowy foreboding of the Victorian Gothic, is reminiscent of the soft golden light and chiaroscuro effects of tenebrism, a style associated with significant Spanish painters of the seventeenth century such as Velasquez and Ribera. Indeed, the film's Spanish-Basque cinematographer Javier Aguirresarobe names such artists - along with Goya - as his central inspirations (Aguirresarobe, 2014). The felt deterritorialization from the film's British influences enhances the sense that Grace, her children, and their household represent a generalized evocation of the historical past detached from a culturally specific narrative.

\section{Conclusion}

Exemplifying the cultural flows and tangle of influences of globalized media culture, the themes and aesthetics of American, Spanish, and Japanese child characters discussed in previous chapters reverberate within these transnational figures, but are deterritorialized to refract the cultural 'between-ness' of transnational cinema. As a result, these figures function as prisms through which anxieties surrounding conceptual and technological change can be illuminated. The embodied site of cultural exchange, the transnational uncanny child becomes bound up in a self-conscious consideration of how the rise of digital media incites a wavering of the boundaries separating national cinemas and traditions, and a concomitant muddying of clear conceptions of national identity. Due to their cultural hybridity, these child characters resist being embedded in secure historical narratives, and, as a result, their growth is unshackled from concepts of national progress and futurity - a process explored in this book's final chapters. The transnational uncanny child thus becomes a complex embodiment of childhood's shifting role in early 21st century society, a cultural moment in which historical meaning and technologies were in flux. 


\section{Works Cited}

Aguirresarobe, Javier. 'Javier Aguirresarobe, ASC, AEC: Interviews with ASC Members.' Theasc.com, American Society of Cinematographers. Feb. 2014. Web. 30 Sep. 2014.

Allen, Nick. 'Hollywood Says Goodbye to Celluloid.' The Telegraph.com, Telegraph UK. 25 Dec. 2011. Web. 30 Sep. 2014.

Balmain, Colette. Introduction to Japanese Horror Film. Edinburgh: Edinburgh University Press, 2008. Print.

—.'Lost in Translation: Otherness and Orientalism in The Ring.' Diagesis: The Journal of the Association for Research into Popular Fictions Special Horror Edition (2004): 69-77. Web. 30 Sep. 2014.

Belton, John. 'Digital 3D Cinema: Digital Cinema's Missing Phase.' Film History 24 (2012): 187-195. Print.

Benson-Allott, Caetlin. Killer Tapes and Shattered Screens: Video Spectatorship from VHS to File Sharing. Berkeley: University of California Press, 2013. Print.

Del Toro, Guillermo. Interview by Ryan Turek. 'On the Set: Guillermo del Toro, Jessica Chastain on the Mysteries of MAMA.' Shocktillyoudrop.com, Shock Till You Drop. 23 Oct. 2012. Web. 30 Sep. 2014.

Deleuze, Gilles and Guattari, Félix. Anti-Oedipus. 1984. London: Continuum, 2004. Print.

Enns, Anthony. 'The Horror of Media: Technology and Spirituality in the RINGU Films.' The Scary Screen: Media Anxiety in The RING. Ed. Kristen Lacefield. Surrey: Ashgate Publishing Ltd., 2010. 29-44. Print.

Ezra, Elizabeth and Rowden, Terry. eds. Transnational Cinema: The Film Reader. London: Routledge, 2006. Print.

Hancock, David. 'The End of an Era Arrives as Digital Technology Displaces 35mm Film in Cinema Projection.' Technology.IHS, IHS Technology. 15 Nov. 2011. Web. 30 Sep. 2014.

Hantke, Steffen, ed. 'They Don't Make 'Em Like They Used To: On the Rhetoric of Crisis and the Current State of American Horror Cinema.' American Horror Film: The Genre at the Turn of the Millennium. Jackson: The University Press of Mississippi, 2010. vii-xxxii. Print.

-.Academic Film Criticism, the Rhetoric of Crisis, and the Current State of American Horror Cinema: Thoughts on Canonicity and Academic Anxiety.' College Literature 34.4 (2007): 191-202. EBSCO Host Humanities International Complete. Web. 30 Sep. 2014.

James, Henry. The Turn of the Screw. 1898. Ed. David Bromwich. London: Penguin Classics, 2011. Print. 
Klein, Christina. 'Globalization and Transnational U.S.-Asian Genres.' American Horror Film: The Genre at the Turn of the Millennium. Ed. Steffen Hantke. Jackson: The University of Mississippi Press, 2010. 3-14. Print.

Lázaro-Reboll, Antonio. Spanish Horror Film. Edinburgh: Edinburgh University Press, 2012. Print.

—.'The Transnational Reception of El espinazo del diablo (Guillermo del Toro 2001).' Hispanic Research Journal 8.1 (2007): 39-51. Maney Online. Web. 30 Sep. 2014.

Lim, Bliss Cua. Translating Time: Cinema, the Fantastic and Temporal Critique. Durham: Duke University Press, 2009. Print.

Lobato, Ramon. Shadow Economies of Cinema: Mapping Informal Film Distribution. London: BFI/Palgrave Macmillan, 2012. Print.

Lowenstein, Adam. 'Globalized Spectatorship: Ring Around the Superflat Global Village: J-Horror Between Japan and America.' Dreaming of Cinema: Spectatorship, Surrealism and the Age of Digital Media. New York: Columbia University Press, 2015. 79-116. Print.

McRoy, Jay, ed. 'Case Study: Cinematic Hybridity in Shimizu Takashi's Ju-ON: THE GRUdGE.' Japanese Horror Cinema. Edinburgh: Edinburgh University Press, 2005. 175-184. Print.

-.Nightmare Japan. Amsterdam: Rodopi, 2008. Print.

Och, Dana and Strayer, Kirsten, eds. Transnational Horror Across Visual Media: Fragmented Bodies. New York: Routledge, 2014. Print.

Parr, Adrian, ed. The Deleuze Dictionary: Revised Edition. Edinburgh: Edinburgh University Press, 2013. Print.

Queenan, Joe. 'Bring on the Creepy Girls.' The Guardian.com, The Guardian News and Media. 22 Feb 2008. Web. 30 Sep. 2014.

Rothkopf, Joshua. 'One Missed Call.' TimeOutNewYork.com, Time Out. 8 Jan. 2008. Web. 30 Sep. 2014.

Tomlinson, John. Globalization and Culture. Chicago: The University of Chicago Press, 1999. Print.

Tyron, Chuck. On-demand Culture: Digital Delivery and the Future of Movies. New Brunswick: Rutgers University Press, 2013.

Wada-Marciano, Mitsuyo. 'J-Horror: New Media's Impact on Contemporary Japanese Horror Cinema.' Horror To the Extreme: Changing Boundaries in Asian Cinema. Ed. Jinhee Choi and Mitsuyo Wada-Marciano. Hong Kong: Hong Kong University Press, 2009. 15-39. Print.

Walter, Brenda S. Gardenour. 'Ghastly Transmissions: The Horror of Connectivity and the Transnational Flow of Fear.' Transnational Horror Across Visual Media: Fragmented Bodies. Ed. Dana Och and Kirsten Strayer. New York: Routledge, 2014. 17-29. Print. 
Wee, Valerie.Japanese Horror Films and their American Remakes. London: Routledge, 2013. Print.

\section{Filmography}

The Abandoned. Dir. Nacho Cerdá. Castelao Producciones, 20o6. Film.

The BAd Seed. Dir. Mervyn LeRoy. 1956. Warner Home Video, 2011. Blu-ray DVD. D@Bbe. Dir. Hasan Karacadag. J-Plan, 20o6. Film.

DARKNESS. Dir. Jaume Balagueró. 2002. Dimension Films, 2005. DVD.

DARK WATER. Dir. Walter Salles. Buena Vista Home Entertainment, 2005. DVD.

The Devil's Backbone [El espinazo Del diablo]. Dir. Guillermo del Toro. 2001.

The Criterion Collection, 2001. Blu-ray DVD.

The Exorcist. Dir. William Friedkin. 1973. Warner Home Video, 2013. Blu-ray DVD. Fragile [Frágiles]. Dir. Jaume Balagueró. 2005. Phase 4 Films, 2010. DVD.

The Grudge. Dir. Takashi Shimizu. Sony Pictures Home Entertainment, 2005. DVD.

The Grudge 2. Dir. Takashi Shimizu. Sony Pictures Home Entertainment, 2007. DVD.

The Grudge 3. Dir. Toby Wilkins. Sony Pictures Home Entertainment, 2009. DVD.

The Innocents. Dir. Jack Clayton. 1961. Criterion Collection Home Entertainment, 2014. Blu-ray DVD.

Ju-ON: The Grudge [Ju-ON]. Dir. Takashi Shimizu. 2002. Lionsgate Home Entertainment, 2005. DVD.

Lake Mungo. Dir. Joel Anderson. Mungo Productions, 2008. Film.

One Missed CALl. Dir. Eric Valette. Warner Home Video, 2008. DVD.

The OMen. Dir. Richard Donner. 1976. Twentieth Century Fox, 2007. Blu-ray DVD.

The Orphanage [El orfanato]. Dir. Juan Antonio Bayona. 2007. New Line Home Video, 2008. Blu-ray DVD.

The Others [Los otros]. Dir. Alejandro Amenábar. 2001. Optimum Home Entertainment, 2011. Blu-ray DVD.

Poltergeist. Dir. Tobe Hooper. 1982. Warner Home Video, 2008. DVD.

Pulse [KaIro]. Dir. Kiyoshi Kurosawa. Magnolia Pictures Company, 2001. Film.

Reincarnation [RINne]. Dir. Takashi Shimizu. 2005. Lionsgate Home Entertainment, 2007. DVD.

RINGU. Dir. Hideo Nakata. 1998. DreamWorks Pictures, 2000. DVD.

The RING. Dir. Gore Verbinski. 2002. DreamWorks Pictures, 2013. Blu-ray DVD.

The RING 2. Dir. Hideo Nakata. 2005. DreamWorks Pictures, 2013. DVD.

The Ring Virus. Dir. Dong-Bin Kim. ADFD, 1999. Film.

Scary Movie 4. Dir. David Zucker. Dimension Films, 2006. Film.

The Sixth Sense. Dir. M. Night Shyamalan. 1999. Hollywood Pictures Home Entertainment, 2000. DVD. 
The Shining. Dir. Stanley Kubrick. 1980. Warner Bros. Entertainment Inc., 2007. Blu-ray DVD.

Star Wars Episode I: The Phantom Menace. Dir. George Lucas. Lucasfilm, 1999. Film.

Stir of EchoEs. Dir. David Koepp. 1999. Lionsgate Home Entertainment, 200o. DVD. 